\title{
Editorial
}

\section{Sustainable Conversion of Renewable Energy Sources}

\author{
Farooq Sher $1, * \mathbb{D}$, Oliver Curnick ${ }^{2} \mathbb{D}$ and Mohammad Tazli Azizan ${ }^{3}$ \\ 1 School of Mechanical, Aerospace and Automotive Engineering, Faculty of Engineering, \\ Environmental and Computing, Coventry University, Coventry CV1 5FB, UK \\ 2 Institute for Future Transport and Cities, Coventry University, Priory Street, Coventry CV1 5FB, UK; \\ Oliver.Curnick@coventry.ac.uk \\ 3 Faculty of Chemical Engineering Technology, University Malaysia Perlis, Kompleks Pusat Pengajian Jejawi 3, \\ Arau 02600, Perlis, Malaysia; tazli@unimap.edu.my \\ * Correspondence: Farooq.Sher@coventry.ac.uk or Farooq.Sher@gmail.com; Tel.: +44-(0)-24-7765-7754
}

Citation: Sher, F.; Curnick, O.;

Azizan, M.T. Sustainable Conversion of Renewable Energy Sources.

Sustainability 2021, 13, 2940. https:// doi.org/10.3390/su13052940

Received: 19 February 2021

Accepted: 25 February 2021

Published: 8 March 2021

Publisher's Note: MDPI stays neutral with regard to jurisdictional claims in published maps and institutional affiliations.

Copyright: (c) 2021 by the authors. Licensee MDPI, Basel, Switzerland. This article is an open access article distributed under the terms and conditions of the Creative Commons Attribution (CC BY) license (https:// creativecommons.org/licenses/by/ $4.0 /)$.

\begin{abstract}
Global energy requirements are rising tremendously because of increasing urbanization and the human population. In the last few centuries, the consumption of fossil fuels has caused increased emissions of greenhouse gases resulting in environmental concerns like global warming, climatic change, and biodiversity loss. As a result, progress in sustainable energy has become the centre of attention in climatic change agenda and economic growth. Until now, various methods of renewable energy production have been extensively studied such as geothermal energy, wind energy, and solar energy. In addition to this, the utilization of biofuels from different sustainable sources are also being considered to reduce greenhouses gas emissions. New approaches and developments are still required for the creation of more sustainable, efficient, and affordable renewable energy systems and for the mitigation of global environmental threats. This special issue aims to advance novel developments in the sustainable conversion of renewable energy, providing up to date, fruitful, and actionable insights into economic, social, and environmental sustainability and includes original research articles and reviews to describe the interaction between renewable fuels, CO2 mitigation, and global warming.
\end{abstract}

Keywords: sustainability; renewable energy sources; climate change; biodiversity; natural resources; mitigation; $\mathrm{CO}_{2}$ mitigation; energy conversion and management

\section{Introduction}

Sustainability refers to the process of people maintaining homeostasis and balance in a changing environment, in which the exploitation of resources is done in a controlled manner to meet the current and future potential human needs and aspirations. Sustainability is achieved by balancing the species and resources within an environment. To maintain this equilibrium, available resources must not be depleted faster than the resources that are naturally generated.

As a result of a continuous agricultural and industrial revolution, we can use light and heat in our homes, irrigate and fertilize crops, contact one another, and travel around the world, and this entire progress is driven by human's ability to find and extract energy for use [1]. This energy requirement is rising tremendously because of increasing human urbanization and population. It is expected that the total use of energy may further increase by $40 \%$ by 2040 [2]. While energy plays an essential role in human's welfare and economic development, it is now also associated with the challenges of sustainability [3].

Global warming and other environmental issues caused by the uncontrolled emissions of greenhouse gases (GHG) are regarded as one of the most critical issues for our future generations [4]. Over the course of a few centuries, the consumption of fossil fuels and extensive deforestation have resulted in increased greenhouse gas concentrations in the atmosphere such as carbon dioxide, nitrous oxide, and methane [5], these greenhouse 
gases play an indispensable role in climate change around the globe [6]. Water vapour is accountable for about two-thirds of the increasing global warming while $\mathrm{CO}_{2}$ is regarded as the primary controlling factor in global warming [7]. As such environmental issues are associated with extensive fossil fuel consumption, increased dependence on renewable energies is the furthermost approach to confront them and it is a widely established fact that greenhouse gases can be significantly reduced with the increased use of various renewable energies [4].

Today, sustainable energy is the centre of attention in climatic change agenda and economic growth [8], attracting concerns from around the globe about approaches of designing pathways for a sustainable transition of energy and energy transitions are being carried out with different processes [9]. With respect to resources and technologies, different methods of energy production including geothermal energy, wind technology, electricity and salinity gradient technologies, and solar heating and cooling have been considered [10]. However, wind energy and solar energy are considered to be the most popular types of renewable energies and their significance is related to their notable features including costeffectiveness, easy utilization, and stability [4]. In addition to this, the utilization of biofuels from different sustainable sources can reduce greenhouses gas emissions, diminishing the use of petroleum [11]. The current production of biofuels (first generation) is primarily based on different food crops such as sugarcane and maize, which can compete with food production and agricultural lands, further impacting biodiversity and ecosystem services directly and indirectly [12].

New approaches and developments are still required for the creation of more sustainable, efficient, and affordable renewable energy systems, and also for the mitigation of global environmental threats including climate change [13]. Researches are contributing towards achieving a sustainable future with developments in cleaner energy generation, distribution and transmission, energy efficiency, storage of electrical and chemical energies, and better management systems [1]. Sustainable energy policies also contribute a significant part in energy transitions as they can act as the driving force behind innovations in renewable energy. Additionally, they are a prerequisite in assembling finance that is an essential factor in achieving climate goals. Thus, the use of policies and regulations can have a positive impact on the outcomes of sustainable energy in the long run [14].

\section{Contents of the Special Issue}

This special issue entitled "Sustainable Conversion of Renewable Energy Sources" includes a collection of nine papers that provide up-to-date and actionable insights into economic, social, and environmental sustainability. Original research articles and reviews have been included that use conceptual models, analytical frameworks, or empirical studies from critical perspectives and in different contexts to describe the interaction between renewable fuels, $\mathrm{CO}_{2}$ mitigation, and global warming.

In the first article, Kim et al., conducted an analysis of the use of energy over time on electrochromic windows which are one of the main types of smart windows. In this research, the optimal properties of electrochromic smart windows were identified, and an operation schedule was created (Contribution 1). Paraschiv et al., presented the hammer mill working process optimization problem for milling energetic biomass. They have analyzed constructive and functional parameters of the hammer mill to reduce the specific energy consumption (Contribution 2). Ullah et al., in their experimental study, presented a method of synthesizing alternative transparent conducting oxides (TCOs) for the reduction or substitution of the use of indium in the preparation of transparent conducting thin films for sustainable and alternative energy production (Contribution 3).

Yaqoob et al., presented their research based on the tribological performance of the tire pyrolysis oil using the four-ball tester. The study provides an insight into the wear and contact attributes of tire pyrolysis oil (TPO) along with its blend with biodiesel fuel at different test boundaries. They have investigated tire pyrolysis oil (TPO), palm biodiesel fuel (BD), and their blends BT10 (biodiesel 90\%, TPO 10\%) and BT20 (biodiesel 80\%, TPO 
20\%) (Contribution 4). Ahmad et al. examined the energy management systems in the iron and steel sector in Pakistan, and also compared them with the research outcomes of similar studies in Bangladesh, Ghana, and Sweden (Contribution 5).

Beig et al., investigated the use of polymeric materials in combination with inorganic substances such as plaster of Paris and sulfur as biodegradable and effective coating substances for urea prills (Contribution 6). Razzaq et al., developed different density and viscosity models and tested them on biodiesel blends taken from different feedstocks including calophyllum, coconut, palm, mustard, and soybean oils (Contribution 7).

In a review, Talip et al. have explored various ionic liquids (ILs) that have been incorporated into different types of dye-sensitized solar cells (DSSCs) electrolytes and gave an insight on to what extent ILs can solve the issues that arise from the usage of organic solvents. The study has also discussed the implications of the DSSCs' efficiency (Contribution 8). And finally, Lu et al., presented a review on sustainable energy policy for the promotion of renewable energy by investigating the development history of energy policy in five countries including China, Denmark, Germany, the United Kingdom, and the United States. Their study is based on a survey of articles promoting the development of sustainable energy policies and their modelling (Contribution 9).

\section{List of Contributors}

1. Kim, J.-H., Hong, Jongin, Han, Seung-Hoon; Optimized Physical Properties of Electrochromic Smart Windows to Reduce Cooling and Heating Loads of Office Buildings.

2. Paraschiv, G., Moiceanu, Georgiana, Voicu, Gheorghe, Chitoiu, Mihai, Cardei, Petru, Dinca, Mirela Nicoleta, Tudor, Paula; Optimization Issues of a Hammer Mill Working Process Using Statistical Modelling.

3. Ullah, S., Branquinho, Rita, Mateus, Tiago, Martins, Rodrigo, Fortunato, Elvira, Rasheed, Tahir, Sher, Farooq; Solution Combustion Synthesis of Transparent Conducting Thin Films for Sustainable Photovoltaic Applications.

4. Yaqoob, H., Teoh, Yew Heng, Jamil, Muhammad Ahmad, Rasheed, Tahir, Sher, Farooq; An Experimental Investigation on Tribological Behaviour of Tire-Derived Pyrolysis Oil Blended with Biodiesel Fuel.

5. Ahmad, I., Arif, Muhammad Salman, Cheema, Izzat Iqbal, Thollander, Patrik, Khan, Masroor Ahmed; Drivers and Barriers for Efficient Energy Management Practices in Energy-Intensive Industries: A Case-Study of Iron and Steel Sector.

6. Beig, B., Niazi, Muhammad Bilal Khan, Jahan, Zaib, Pervaiz, Erum, Abbas Shah, Ghulam, Ul Haq, Midrar, Zafar, Mazhar Iqbal, Zia, Munir; Slow-release Urea Prills Developed using Organic and Inorganic Blends in Fluidized Bed Coater and their Effect on Spinach Productivity.

7. Razzaq, L., Farooq, Muhammad, Mujtaba, MA, Sher, Farooq, Farhan, Muhammad, Hassan, Muhammad Tahir, Soudagar, Manzoore Elahi M, Atabani, AE, Kalam, MA, mran, Muhammad; Modeling Viscosity and Density of Ethanol-Diesel-Biodiesel Ternary Blends for Sustainable Environment.

8. Abu Talip, R.A., Yahya, Wan Zaireen Nisa, Bustam, Mohamad Azmi; Ionic Liquids Roles and Perspectives in Electrolyte for Dye-Sensitized Solar Cells.

9. Lu, Y., Khan, Zafar A, Alvarez-Alvarado, Manuel S, Zhang, Yang, Huang, Zhijia, Imran, Muhammad; A Critical Review of Sustainable Energy Policies for the Promotion of Renewable Energy Sources.

\section{Conclusions}

In conclusion, this special issue including original research articles and reviews based on conceptual models, analytical frameworks, or empirical studies from critical perspectives, covers a broad range of different topics regarding the sustainable conversion of renewable energy resources and provide insights on how renewable energy can be produced sustainably to fulfil our future energy demands while reducing negatives impacts on environmental health such as global warming and climatic change. In future, more work 
should be carried out to address strategies and novel approaches in the developments of sustainable energy conversion because the world continues to face the impacts of increasing global warming and climatic change.

Author Contributions: Conceptualization, Methodology, Software, Validation, Formal Analysis, Investigation, Resources, Data Curation, Project Administration, Funding Acquisition, Visualization, Supervision, Writing — Original Draft Preparation, Writing—Review and Editing, F.S.; WritingOriginal Draft Preparation, Software, Formal Analysis, Validation, Investigation, Resources, Data Curation, Project Administration, O.C. and M.T.A. All authors have read and agreed to the published version of the manuscript.

Funding: This research received no external funding.

Acknowledgments: The authors are highly obliged to their respective institutes for financial support.

Conflicts of Interest: The authors declare no conflict of interest.

\section{References}

1. Chu, S.; Cui, Y.; Liu, N. The path towards sustainable energy. Nat. Mater. 2017, 16, 16-22. [CrossRef] [PubMed]

2. Cronshaw, I. World Energy Outlook 2014 projections to 2040: Natural gas and coal trade, and the role of China. Aust. J. Agric. Resour. Econ. 2015, 59, 571-585. [CrossRef]

3. Mundaca, L.; Busch, H.; Schwer, S. 'Successful' low-carbon energy transitions at the community level? An energy justice perspective. Appl. Energy 2018, 218, 292-303. [CrossRef]

4. Razmjoo, A.; Qolipour, M.; Shirmohammadi, R.; Heibati, S.; Faraji, I. Techno-economic evaluation of standalone hybrid solar-wind systems for small residential districts in the central desert of Iran. Environ. Prog. Sustain. Energy 2017, 36, 1194-1207. [CrossRef]

5. Shukla, P.; Skea, J.; Calvo Buendia, E.; Masson-Delmotte, V.; Pörtner, H.O.; Roberts, D.C.; Zhai, P.; Slade, R.; Connors, S.; Van Diemen, R.; et al. Climate Change and Land: An IPCC Special Report on Climate Change, Desertification, Land Degradation, Sustainable Land Management, Food Security, and Greenhouse Gas Fluxes in Terrestrial Ecosystems; Intergovernmental Panel on Climate Change (IPCC): Geneva, Switzerland, 2019.

6. Shurpali, N.; Agarwal, A.K.; Srivastava, V. Greenhouse Gas Emissions: Challenges, Technologies and Solutions; Springer: Berlin/Heidelberg, Germany, 2018.

7. Al-Ghussain, L. Global warming: Review on driving forces and mitigation. Environ. Prog. Sustain. Energy 2019, 38, $13-21$. [CrossRef]

8. Baiardi, D. Do sustainable energy policies matter for reducing air pollution? Energy Policy 2020, 140, 111364. [CrossRef]

9. Chen, B.; Xiong, R.; Li, H.; Sun, Q.; Yang, J. Pathways for sustainable energy transition. J. Clean. Prod. 2019, 228, 1564-1571. [CrossRef]

10. Østergaard, P.A.; Duic, N.; Noorollahi, Y.; Mikulcic, H.; Kalogirou, S. Sustainable Development Using Renewable Energy Technology; Elsevier: Amsterdam, The Netherlands, 2020.

11. Bórawski, P.; Bełdycka-Bórawska, A.; Szymańska, E.J.; Jankowski, K.J.; Dubis, B.; Dunn, J.W. Development of renewable energy sources market and biofuels in The European Union. J. Clean. Prod. 2019, 228, 467-484. [CrossRef]

12. Correa, D.F.; Beyer, H.L.; Possingham, H.P.; Thomas-Hall, S.R.; Schenk, P.M. Biodiversity impacts of bioenergy production: Microalgae vs. first generation biofuels. Renew. Sustain. Energy Rev. 2017, 74, 1131-1146. [CrossRef]

13. Strezov, V.; Anawar, H.M. Renewable Energy Systems from Biomass: Efficiency, Innovation and Sustainability; CRC Press: Boca Raton, FL, USA, 2018.

14. Bank, T.W. Policy Matters: Regulatory Indicators for Sustainable Energy. World Bank. 2018. Available online: www.worldbank.org/ en/topic/energy/publication/rise-2018 (accessed on 14 February 2021). 